\title{
Mapping Typha Domingensis in the Cienega de Santa Clara using Satellite Images, Global Positioning System, and Spectrometry
}

by Richard D. Sanchez, Earl Burnett, and Fred Croxen

Open-File Report 00-314

U.S. Department of the Interior

U.S. Geological Survey 


\title{
MAPPING TYPHA DOMINGENSIS IN THE CIENEGA DE SANTA CLARA USING SATELLITE IMAGES, GLOBAL POSITIONING SYSTEM, AND SPECTROMETRY
}

\author{
Richard D. Sanchez \\ U.S. Geological Survey \\ 521 National Center \\ Reston,Va 20192
Earl Burnett and Fred Croxen
Bureau of Reclamation
Yuma Area Office
Yuma, Az 85366

\begin{abstract}
The Cienega de Santa Clara, Sonora, Mexico, a brackish wetland area created near the delta of the Colorado River from drainage effluent flowing from the United States since 1977, may undergo changes owing to the operation of the Yuma Desalting Plant in the United States. This has become the largest wetland in the delta region containing rare and endangered species, yet little is known about the environmental impact of these changes. The water quality of the marsh is of growing concern to the Bureau of Reclamation (BOR) which operates the Desalting Plant. Consequently, the BOR solicited the U.S. Geological Survey to investigate the limits and usefulness of satellite, global positioning system (GPS), and spectra data to map the Typha domingensis (cattail) of the Cienega de Santa Clara.
\end{abstract}

Typha domingensis was selected by the BOR as the Cienega de Santa Clara indicator species to best predict the environmental effects of effl uent from the Yuma Desalting Plant. The successful base mapping of Typha domingensis will provide a viable tool for long-term monitoring and stress detection in the Cienega de Santa Clara.

\section{INTRODUCTION}

Over the last 20 years, scientists have used satel lite data to map wetlands. From as far back as the early 1970 's, studies have been made to determine the usefulness of satellite imagery for the inventorying and monitoring wetland areas. Morrow and Carter (1978) were among the first to use Cowardin's (1977) wetland classification scheme to test Landsat data and establish basic techniques for the visual and automated classification of wetlands. Work by Pfeiffer and others (1973), Jensen (1980), and Bartlett and Klemas (1981) showed that spectral reflecta nce measurements from salt marsh plants could be used to describe various canopy characteristics, just as reflectance measurements of crops were being used similarly in agriculture.

The use of trade, product, or firm names in this publication is for descriptive purposes only and does not imply endorsement by the U.S. Government. 
The Cienega de Santa Clara, an International Biosphere Reserve, is an emerging nonforested brackish wetland situated near the Colorado River delta area of Sonora, Mexico. Created by drainage effluent flowing from the United States since 1977, it has become the largest wetland in the delta region containing rare and endangered species. Little is known about the environmental impact of changes that may oc cur owing to the operation of the Yuma Desalting Plant in Arizona. The quality and quantity of water flowing into the marsh is of growing concern to the Bureau of Reclamation (BOR), which is responsible for the operation of the Yuma Desalting Plant under Title 1 of the Colorado River Basin Salinity Control Act (P.L. 93 -320). Although BOR's mandate relates to the salinity of the Colorado River above the Morelos Dam, providing a stable environment downriver of the Yuma Desalting Plant has recently become ve ry important to Mexico. Because of this growing concern, the BOR solicited the U.S. Geological Survey (USGS) to investigate the applicability of remote sensing, the global positioning system (GPS), and spectrometry for base mapping the Cienega de Santa $\mathrm{Cl}$ ara Typha domingensis to assist in determining future environmental effects of changes in water volume and salinity level that may occur should the Yuma Desalting Plant begin operation.

The Yuma Desalting Plant is a 73 -million gallon a day desalting plant using reverseosmosis membrane technology. The plant, which went on line in 1992, draws its water supply from groundwater pumped from the Wellton -Mohawk Irrigation and Drainage District located along the Gila River east of Yuma, Ariz. Currently, the wa ter quality requirements of Minute 242 of the 1944 U.S./Mexico Water Treaty are being met through bypassing the Wellton-Mohawk drainage returns around the Morelos Dam and through releases of surplus water from the Colorado and Gila Rivers. The plant has been in ready reserve status since January 1993. When the plant was in operation up to 33 percent capacity during 1992, this brackish water supply of about 3,000 parts per million (ppm) of total dissolved solids was desalted and returned to the Colorado R iver for delivery to Mexico at the Morelos Dam. The desalting plant's reject stream, a highly saline effluent, was blended with the remaining drainage returns from the Wellton Mohawk Irrigation and Drainage District and carried to the Cienega de Santa Cla ra by a canal referred to in the past as the Wellton-Mohawk Drainage Extension or MODE, as well as the Wellton-Mohawk Bypass Drain (herein the canal will be referred to as the Bypass Drain). This $80-\mathrm{km}$ (49.6 mi) canal, which began carrying water into the Cienega de Santa Clara in1977, is expected to carry a reject stream of up to $10,000 \mathrm{ppm}$ at a flow rate of about 28,000 acre-ft/yr when the plant is in at full operation. The current discharge to the Cienega de Santa Clara ranges from 90,000 to 100,000 acre - $\mathrm{ft} / \mathrm{yr}$.

Few detailed surveys have been made of the newly formed Cienega de Santa Clara until recently. In 1979 Glenn and others (1992) visited the area and observed that a large brackish water lake had formed at the discharge end of the Bypass Drain. T his was further documented in a Bureau of Reclamation report in 1980. In 1993, Burnett and others (1993, revised 1997) provided commentary of the site's geology, hydrology, and cattail salt tolerance. A report by Glenn and others (1994) describes experim ents to determine the salt tolerance, distribution, and evapotranspiration of cattails in the Cienega de Santa Clara. 


\section{Purpose of Study}

The general goal of this project is to investigate the applicability of remote sensing, GPS, and spectrometry for base mapping the Cienega de Santa Clara Typha domingensis (herein referred to as Typha). To fulfill this goal, we established the following objectives. (1) evaluate the use of subpixel classification to detect and differentiate pixels containing predominantly Typha and mixed-Typha spectra, (2) assess the usefulness and limits of the satellites images, GPS, and spectrometry for mapping the Cienega de Santa Clara Typha, and (3) generate from the results of the investigation a database of the Cienega de Santa Clara Typha. The resultant base data will be applied by BOR in a separate study to assess the relationships between variability in wetland change patterns and to define the environmental setting and the impact of saline effluent into the Cienega de Santa Clara from the Yuma Desalting Plant.

\section{Project Area and Source Data}

The Cienega de Santa Clara is situated in the far northeastern corner of the Colorado River delta in the State of Sonora, Mexico (see figure 1). The Spanish term "cienega" is translated in English as "marsh"; hence, the literal translation is marsh of the Santa Clara, or Santa Clara Marsh. The general site location is centered on latitude 32 degrees, 1 minute, $08^{\prime \prime} \mathrm{N}$. and longitude 114 degrees, 52 minutes, $42 " \mathrm{~W}$. at an elevation range of 0 to 40 meters mean sea level. As of January1998, the Cienega de Santa Clara was approximately $13 \mathrm{~km}$ long (bearing 134 degrees) and $7 \mathrm{~km}$ (bearing 55 degrees) at its widest point.

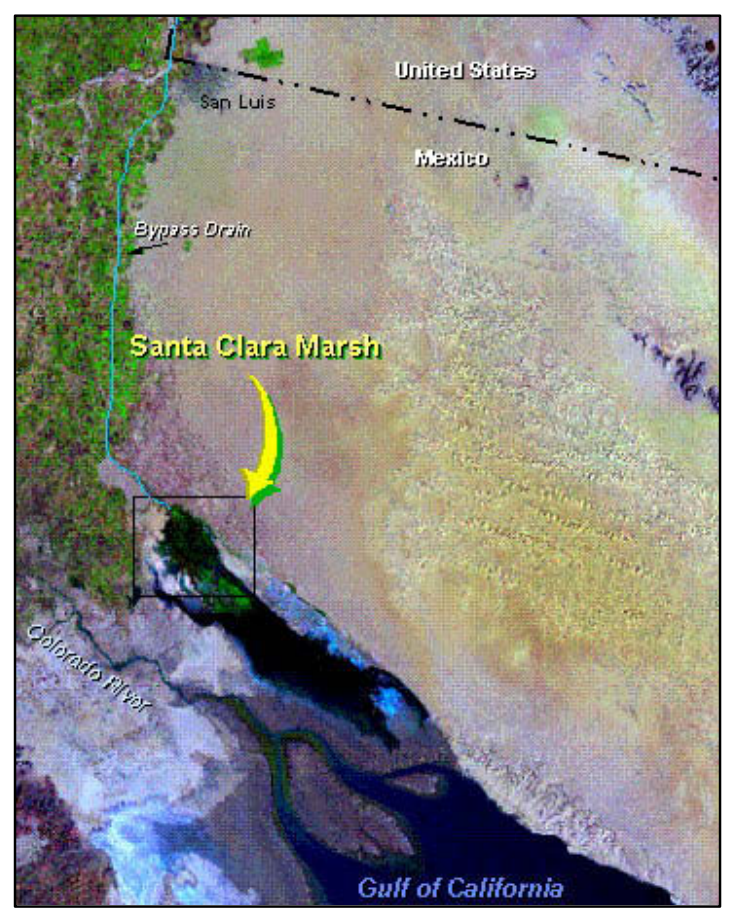

Figure 1. Location of project study area. 
This emergent wetland has been fo rmed on the upper northwestern end of a basin cut off from the Gulf of California by a natural land barrier along its lower southeastern fringe (Burnett and others, 1993). In the past, the entire basin was mistakenly mapped by the Bureau of Reclamation as the Santa Clara Slough, a tidal channel entering the Gulf (shown near El Muelle on an Instituto Nacional de Estadística, Geografía e Informatíca 1:50,000-scale topographic map). Herein, to maintain clarity, the Cienega de Santa Clara will refer to the vegetative marsh only.

Very little marsh vegetation existed (see fig. 2) or was documented in the project area before 1977. Today, the marsh is inhabited predominately by Typha, or cattail. Other vegetation, such as salt grass (Distichlis spicata), saltbush (Atriplex canescens), common reed (Phragmites australis), and bulrush (Scirpus americanus) also thrive. Beyond the Colorado River valley and delta area, the Sonoran Desert's very low precipitation limits the natural vegetation to shrubby plants.

The satellite data acquired for this project were collected by Landsat multispectral scanner (MSS) on September 20, 1972, December 29, 1972, and November 29, 1976 (MSS scenes, Path 41, Row 38), and Landsat thematic mapper (TM) on October 10, 1988, December 17, 1995, January 23, 1998, and February 6, 2000 (TM scenes, Path 38, Row 38), under clear atmospheric conditions. The multidate scenes were acquired around the same time of year to increase the probability that the measured ground changes are not seasonal reflectance differences. Satellite image views from the multidate scenes provide a quick visual comparison of the state of growth of the marsh (fig. 2).

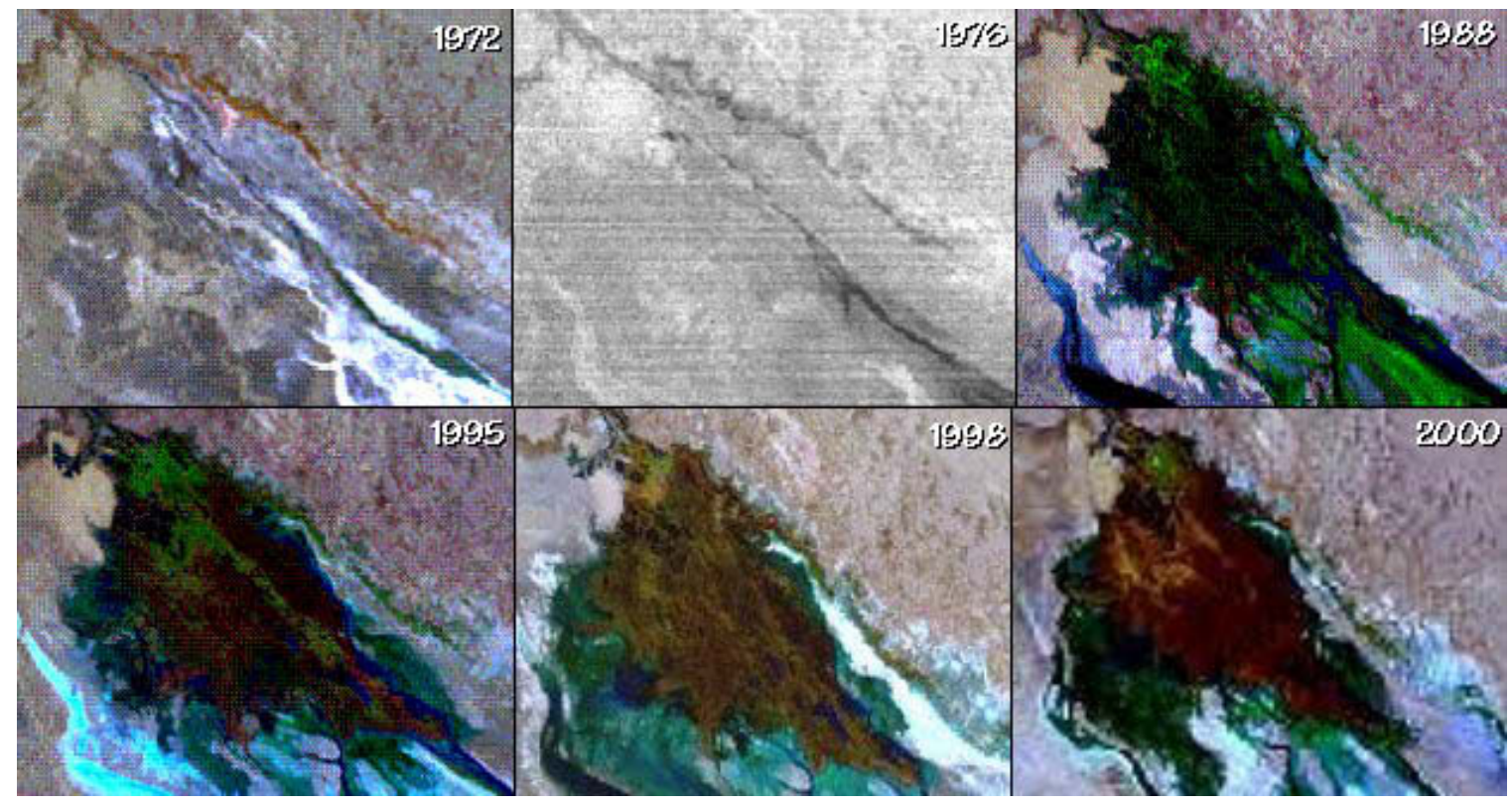

Figure 2. Multidate satellite views of the Cienega de Santa Clara (inset). 
In this study, the data from the thermal band (TM band 6) with a pixel size of $120 \mathrm{~m}$ were not used.

The equipment that made up the field mapping components in this project included a precise positioning service (PPS) Rockwell Precise Light -Weight GPS Receiver (PLGR) and a Laser Atlanta Advantage Range-Finder unit. Two BOR standard positioning service (SPS) Trimble Pathfinder Pro XL GPS receivers provided backup support. Spectra was collected from a 350 to 2,500 nanometers $(\mathrm{nm})$ full range Analytical Spectral Device (ASD) FieldSpec Spectrometer. The field mapping software installed on a laptop computer included GeoLink Powermap, ERDAS Imagine (with Arc/Info Vector and Subpixel Classifier Modules), and Arc/View.

Other source materials include the Mexico Instituto Nacional de Estadística, Geografía e Informatíca 20 - by 15-minute topographic maps of Oviedo Mota I11D87 (1982) and El Doctor H11B17 (1981) on Universal Transverse Mercator projection, zone 11, with 1,000-meter grid spacing, North American Datum 27, and Clarke 1866 Spheroid. In addition to the PC-based software above, the USGS used ERDAS Imagine software on a Unix-based SGI workstation to process the raster and vector base data. Arc/Info software was also used to collect, attribute, and symbolize the vector base data.

\section{INSTRUMENTATION AND PROCEDURES}

The fieldwork was conducted during the month of January 1998. To know the precise grid coordinate of any point in the Cienega de Santa Clara, the field team established a network of 34 well-distributed, image-identified ground control points. These points were used in a least square regression analysis to derive a first -order polynomial transformation of the 1998 TM image with less than a 1 -pixel root-mean-square error. Following the registration and nearest neighb or resampling at an output pixel size of 30 by $30 \mathrm{~m}$, we applied image-to-image registration to the 1988, 1995, 1998, and 2000 Landsat scenes ( 80 by $80 \mathrm{~m}$ for 1972 and 1976 scenes). Because the study area is relatively flat, correction for terrain displacem ent, or orthorectification, was deemed necessary.

A series of field surveys were conducted using a PLGR, a Laser Atlanta Advantage Range Finder, a digital camera, and a laptop PC installed with a GeoLink software interface with the GPS receiver and laser range-finder unit. The GPS receiver antenna was magnetic-mounted on a field pack pole. This allowed the laptop operator to display the satellite image tile and track the footpath or path of the vehicle in real time. Stops were made to identify, collect, and photograph feature and attribute data. In addition, soil core and water samples were collected for post analysis (see Water and Soil Data, Appendix B). Information regarding vegetation condition and other feature attributes was entered into the computer simultaneously with GPS coordinates and was also recorded on field log sheets. The displayed image backdrops were easily tracked and linked to specific coordinates because of the GPS interface.

The GPS receiver computes accurate position coordinat es, elevation, speed, and time 
information from signals transmitted by NAVSTAR GPS satellites. The PLGR provided precise positioning service of the NAVSTAR GPS at approximately $0-6 \mathrm{~m}$ vertical and horizontal accuracy or Circular Error Probability (U.S. De partment of Defense, 1984) in real time without differential correction. During the time of collection, fewer than five GPS satellites were in view above the horizon, providing full coverage in three dimensions.

To gain the full benefit of the Landsat multispectral images, we applied ground -truthing field spectrometry techniques within a minimum of 30 - by 30 -meter polygons representing a pixel in a TM image. Although the spectral resolution range of 400 to $1,000 \mathrm{~nm}$ is ideal for the distinct signature $\mathrm{p}$ roduced by green vegetation, the 350 to 2,500 $\mathrm{nm}$ full range of the spectrometer used for spectral mapping offered a greater capability to analyze spectra groups in the project area. The field team took spectra measurements between 10 a.m. and 3 p.m. when the sun was at its highest above the horizon. Each target measurement was taken from a height of approximately 1 meter over the canopy, aiming vertically and facing the sun. Most of the spectra measurements were taken on the same day as the Landsat overp ass. The instrument operator calibrated the spectrometer 20 to 30 times a day to compensate for subtle changes in atmospheric humidity, sun angle, and high-altitude haze and dust that can introduce unwanted characteristics into the sample spectra. Incre ased spectrum averaging was necessary to see though the noisy spots.

\section{SPECTRAL CHARACTERIZATION AND MAPPING}

Because of its vigor, salt tolerance, and profusion, Typha was selected by BOR as the wetland indicator species for estimating the future environm ental impact of effluent from the Yuma Desalting Plant. The Cienega de Santa Clara dominant Typha domingensis is an erect, perennial herb 1-4 m tall with long, linear leaves sheathing at the base, growing on wet substrates and often in 1 meter of standing water. The deep green leaves are 1-2 $\mathrm{cm}$. wide and extend above the spike. The flowers are packed into dense, cylindrical spikes. Typha spreads extensively by rhizomes so that a hectare of Typha in the Cienega de Santa Clara may consist of only a few ind ividual plants. It provides important food and cover for the Cienega de Santa Clara wildlife. In addition, Typha forms floating mats, and its foliage provides resting and nesting sites for Cienega de Santa Clara water birds, such as the American coot, sn owy egret, black-crowned night heron, and the endangered Yuma Clapper Rail. Differences exist among the Cienega de Santa Clara Typha stands; generally, the taller more robust stands are at the northern part of the marsh near the discharge point, where wat er is less than 3,000 ppm salinity.

\section{Framework}

Before collecting field spectra we developed, a classification scheme to provide the framework for mapping Typha in the Cienega de Santa Clara. Applying Cowardin's (1977) outline, scientist can generally define the Cienega de Santa Clara as an estuarine (Ecological System) emergent wetland (Class) that is mineral organic (Order), intermittently flooded (Water Regime), brackish or slightly saline (Water Chemistry), fed 
primarily by canals (Special Modifiers), and occupying over 4,047 hectares, or 10,000 acres (Acreage). Water type by Davis and DeWiest (1967) is defined as concentration of total dissolved solids in parts per million, as follows: fresh water is $<1,000 \mathrm{ppm}$, brackish water is $1,000-10,000 \mathrm{ppm}$, salty water is $10,000-100,000 \mathrm{ppm}$, and brine is $>100,000$ ppm. Currently, the Cienega de Santa Clara falls in the brackish water type (salinity varying from 2,700 to $3,200 \mathrm{ppm}$ ).

\section{Detection and Mapping}

Because of the heterogeneity of wetland areas owing to their variety of plant communities as well as to their location within an environment of varying moisture and saline content, spectral signatures are often overlapping and mixed with background materials. This mixed spectral signature problem was ev ident in the detection of Typha in the Cienega de Santa Clara. For example, each image pixel often consists of mixed vegetation and background material such as Distichlis spicata (salt grass), Phragmites australus (common reed), and Scirpus americanus (bulrush), plus marsh debris and water. Several classification techniques or processes based on principal component analysis and linear mixing models can be used to resolve this pixel problem (Huguenin, 1994). Unlike the process used in the linear spectral unmixing subpixel models, the ERDAS Subpixel Classifier was applied in this study to detect whole and subpixel occurrences of Typha.

After removing the spectral distortion of atmosphere and sun angle effect from the image, we developed reference signatur es from the geocoded $>30$ - by $30-\mathrm{m}$ polygons collected in the field or created from known Typha stands. The principal restrictions were that the amount of Typha in the training pixels needed to exceed about 20 percent of the pixel and that the Typha should have relatively unique and consistent spectral properties. The Subpixel Classifier automatically did pixel -by-pixel searches for Typha, first using differences from the reference signature to characterize the background spectral properties. These background characteristics are used to automatically select pixels from the scene that are candidate backgrounds and to estimate how much background is contained in the pixel being evaluated. For each pixel being evaluated, the candidate backgrounds are tested, and the one that produces a residual spectrum most similar to the reference signature is selected. If the residual spectrum agrees with the reference signature within an allowed set of tolerances, the pixel is identified as containing Typha. If the residual falls outside of the tolerance limits, the pixel is rejected as not containing a detectable amount of Typha. In figure 3, a sample of the background removal of Typha stands in the Cienega de Santa Clara is shown in the inset of the northeastern part of the marsh near the Bypass Drain discharge point, covering an area of $>10 \times 10 \mathrm{~km}$. Color coded pixels in the legend indicate the percentage of each image pixel occupied by Typha. Some of the detections contain as little as 20 -percent Typha. The light, colorcoded, mixed pixels are occupied by less saline -tolerant vegetation and will more than likely be affected first with increasing levels of water salinity in the marsh. As an increase in salinity occurs, a gradual increase in the number and percent age of the more salt-tolerant, color-coded Typha pixels is anticipated 
After the 1998 scene-specific environmental correction was applied, the extent of Typha was identified from scene to scene to map the changes before and after the 1977 Bypass Drain construction.

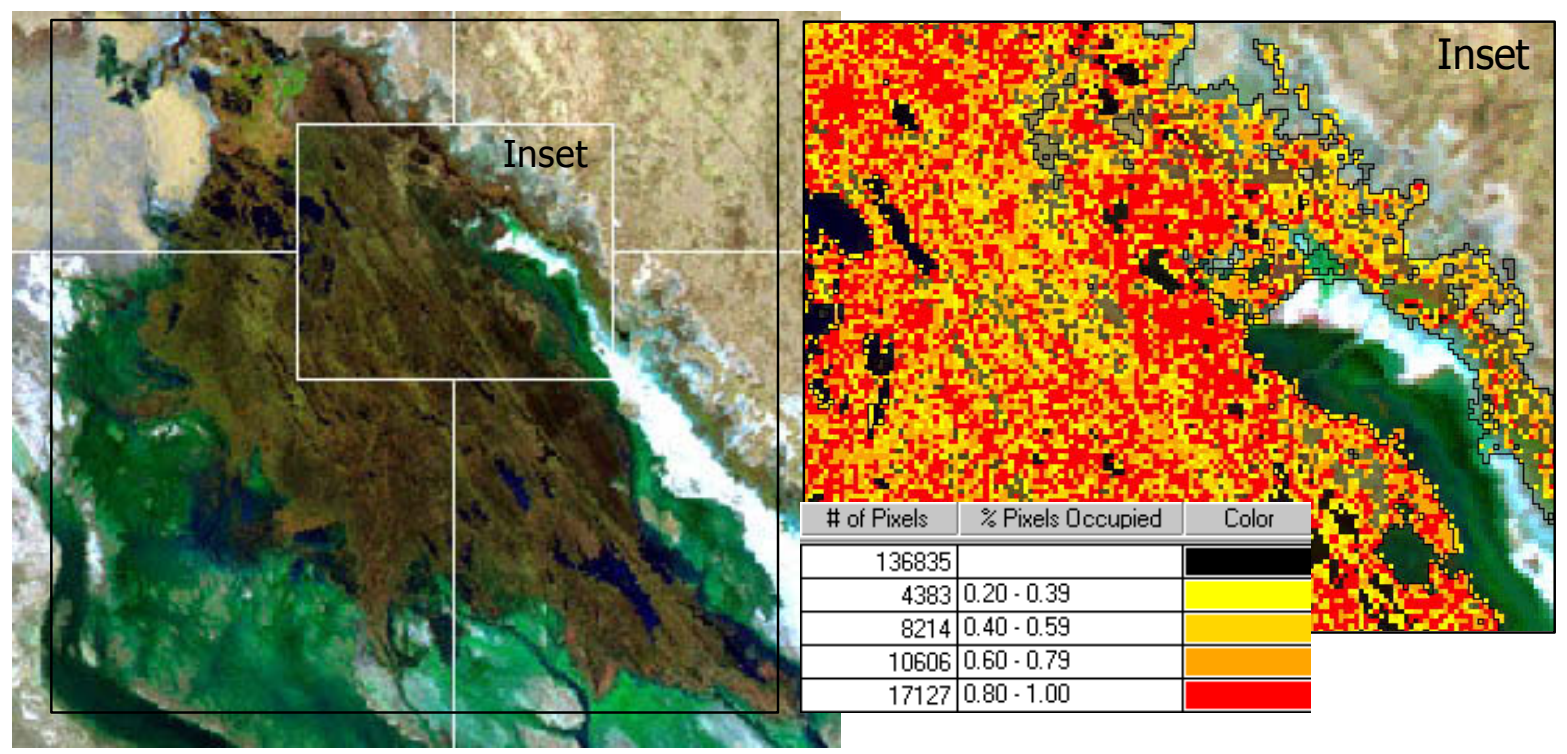

Figure 3. Detection of Typha (inset) in 1998 Landsat TM image.

\section{Accuracy Evaluation}

The Typha classification results were reviewed for interpretation accuracy by comparing the coverage that had been correctly identified from ground -verification sample points and from high-resolution digital images. This interpretation accuracy is defined as the proportion correctly interpreted on the map when compared to the ground truths established from the source materials gathered in the field ( Sturdevant, 1981). We obtained the ground-verification sample points by randomly selecting a set of grid -line intersections (sample points), plotting them on a 1:50,000 -scale color image map of the area, and visiting these points in the field during Janua ry 2000. The field visit consisted of locating each point and noting the land cover for that area. Using the overlay capability of the image processing system, we overlaid the Typha layer on the image and compared it with all the available ground truth i nformation. When compared to ground truth, the resultant map accuracy was about 80 percent (sampling error of \pm 5 percent).

\section{SUMMARY ANALYSIS AND FINDINGS}

An examination of the Landsat images of the 1977 pre -Bypass Drain period shows the areal extent of the Cienega de Santa Clara vegetation as approximately: 436 ha $(1,077$ acres) in December 1972. The BOR reported in 1975 that the upper and lower marsh areas had shrunk to 30 ha ( 74.13 acres) and 180 ha (444.8 acres), respectively. The area during this period was fed by agricultural runoff and by brackish -water seeps. The 
November 1976 satellite image shows an increase in the vegetated marsh to approximately 814 ha (2,011 acres). Post-Bypass Drain calculations of the marsh size from the October 1988 satellite image show that the vegetated marsh grew to 2,911 ha (7,194 acres), a result of nearly 12 years of water flowing into the Cienega de Santa Clara from the Wellton-Mohawk Irrigation and Drainage District. During site visits in 1992, Glenn and others (1992) reported that the northernmost one -third of the marsh was inhabited by cattail 3-4 $\mathrm{m}$ tall and scattered patches of common reed (Phragmites australis) and bulrush (Scirpus americanus). He also reported that in other parts of the marsh there were numerous halophytic and associated wetland species. In a fly-over by helicopter on July 21, 1993, Burnett reported a vegetated marsh area of 10,600 acres and that mostly cattails were found at the discharge end of the Bypass Drain. Based on calculations of the mapped polygons from the processed satellite images in this study, the approximate areal extent of the vegetated marsh was as follows: December 1972, 436 ha (1,077 acres); November 1976, 814 ha (2,011 acres); October 1988, 2,911 ha (7,194 acres); December 1995, 4,555 ha (11,256 acres); January 1998, 4,467 ha (11,039 acres); and, February 2000, 4,187 ha (10,346 acres). Typha was the dominant vegetation cover for each of those periods.

Since 1977, the Riito canal and Bypass Drain have provided about 80 percent of the water to the Cienega de Santa Clara. Other inflow is from a local sewer drain and ground water. According to Burnett and others (1993), 133,250,600 cubic meters (108,028 acre feet) of water with total dissolved solids of 3,495 ppm flowe d into the Cienega de Santa Clara during 1977. Further, an average quality of water at 2,942 ppm flowed into the Cienega de Santa Clara during 1977 to 1993 at an average flow of 5.5 cubic meters per second (195 cfs). During that period, Burnett goes on t o report, the dissolved solids concentration near the mouth of the Bypass Drain (northwestern end of the marsh) which averaged 1,000 ppm in March 1993 because of the mixing of the Gila River floodwater, had increased to 3,000 ppm in July, while concentrati on at the southern end of the marsh increased from approximately 2,000 ppm in March to 9,000 ppm in July 1993.

In 1993, Glenn and others (1994) reported that vigorous Typha, or cattail stands, were found only in water with less than 3,000 ppm salin ity, and all but a single stand were found in water of 5,000 ppm or lower; the exception was a single stand in water of 8,000 ppm. Burnett and others (1993) state that the salt tolerance of Typha is around 5,000$6,000 \mathrm{ppm}$.

Intermittent regional flooding of the Colorado and Gila Rivers is known to occur and has influenced the flow conditions and salt balance of the marsh (Burnett and others, 1993). During January-May1993, the Gila River flooded the Bypass Drain causing high flows at low salinity. However, during repairs to the Bypass Drain after the flood, inflow to the marsh ceased, resulting in a decrease in water flow and increase in salinity. Both events make it difficult to determine the true discharge impact on the biology of the marsh from the operation of the Yuma Desalting Plant in1992 -93. It should be noted that during the above period, six wells in the Yuma Valley delivered water into the Bypass Drain to provide a continuous water supply and avoid any long -term outages (Russ Reichelt, oral commun., May 22, 2000). 
This paper does not project the future discharge impact of the Yuma Desalting Plant operation on the biology of the wetland area. Because of the significance of correctly determining at what capacity the plant could operate and how mu ch saline water can be released into the marsh without destroying the riparian habitat, satellite monitoring during low levels (less than 50 percent of capacity) of plant operation is recommended.

Because of the assortment of Cienega de Santa Clara Typha plants in size, location, and vigor depends on the influences of water and soil quality and quantity, their spectral properties were found to be wide-ranging, yet together provided a very discriminating signature (see Spectral Properties Data, Appendix A). To map full use of the subpixel classifier and improve classification accuracy, we used a multiple signature approach. The need for a multiple signature approach was evidenced by the discovery during signature derivation that there was more than one opti mal material pixel fraction for the training set and that the best performance was achieved using classification results in combination rather than individually. The subpixel classifier made it easier to identify Typha at various levels of density. Mixed Typha was the most difficult to recognize from the satellite images and benefited the most from the use of ground -truthing and subpixel classification.

Developing a field strategy is important to successful data collection. Also, ample time should be dedicated to designing the database (Sanchez and Hothem, 1998). Field logs are recommended for recording anomalous situations, marsh conditions, and any other factors that could affect data quality, data collection, and interpretation. We found that adhering to a checklist maximized time efficiency and prevented many human errors. It is also very important to periodically check the accuracy of the GPS -determined positions at stations with known high-accuracy coordinates.

\section{CONCLUSION}

Many of the early applications of remote sensing to wetlands used aerial photographs rather than applying digital image analysis techniques on low spatial and spectral resolution Landsat data. This was because of the heterogeneity of wetland areas owing to diverse plant communities, as well as to their location within an environment of varying moisture content; spectral signatures are often overlapping, which results in confusion for most classifiers. A combination of archived Landsat satellite data, GPS, field spectrometry, and subpixel classification techniques were applied successfully to map the areal extent of vegetation (see Table 1) and the density of Typha in the Cienega de Santa Clara from 1972 to the present.

Table 1. Areal extent of Cienega de Santa Clara vegetat ion, by year

\begin{tabular}{l} 
YEAR \\
\hline 1972 \\
1976 \\
1988 \\
1995 \\
1998 \\
2000
\end{tabular}

$\frac{\text { HECTARES }}{436 \mathrm{ha}}$
$814 \mathrm{ha}$
$2,911 \mathrm{ha}$
$4,555 \mathrm{ha}$
$4,467 \mathrm{ha}$
$4,187 \mathrm{ha}$

\begin{tabular}{|c} 
ACREAGE \\
\hline 1,077 acres \\
2,011 acres \\
7,194 acres \\
11,256 acres \\
11,039 acres \\
10,346 acres
\end{tabular}


Greater detail about Typha than is usually possible was achieved in the project area using computer analysis of Landsat data. Applying the database generated in this study to monitor the wetland will provide valuable data Cienega de Santa Clara that can be measured to better assess the effect of the desalting plan t's reject stream flowing into the Cienega de Santa Clara. For example, decreases in the less salt -tolerant vegetation should show an increase in the density, or percentage, of Typha in the mapped mixed pixel areas of the marsh. Further, applying the spe ctrometry and classification procedures in this study, scientists should be able to identify other vegetation, such as salt grass (Distichlis spicata), saltbush (Atriplex canescens), common reed (Phragmites australis), and bulrush (Scirpus americanus ), to monitor and estimate the quality and quantity of water needed to sustain specific Cienega de Santa Clara habitats. (The Cienega de Santa Clara database files are stored on compact disk in ArcView -compatible format).

With the availability of commerciall y produced 1 - to 4-m resolution satellite data, the potential application of higher spatial resolution images and airborne hyperspectral sensor data will increase the flexibility for greater intuitive and contextual analysis of the Cienega de Santa Clara database.

\section{ACKNOWLEDGMENTS}

The authors would like to thank the following for their contributions to this project. From the United States: Carroll Brown, Lynette Elser, Ed Kandl, John Kirkaldie, Rob Palmer, Russell Reichelt, Paul Rose, Julian de Santiago , and Don Young, BOR Yuma; Al Goff, IBWC; and Kelly Roberts and Robert Huguenin, Applied Analysis, Inc. From Mexico: Ing. Franciso Bernal, Ing. Alfredo de la Cerda Regis, and Ing. Juan Alfredo Rios Moreno Perez, CILA; Bio. Jose R. Campoy, and Tec. Bernabe Rico Olague, SEMARNAP; Ing. Antonio Espinosa, Biol. Manuel Fernandez Calderon, and Ing. Rafael Miranda Maciel, CNA. Plus thank to many others from both sides of the border, too numerous to list here.

\section{REFERENCES}

Bartlett, D.S., and Klemas, V., 1981, In situ Spectral Reflectance Studies of Tidal Wetland Grasses: Photogrammetry, Engineering and Remote Sensing Journal, vol. 47, p. 1695-1703.

Burnett, E., Kandl E., and Croxen, F., 1993, Cienega de Santa Clara: Geologic and Hydrologic Comments Yuma, Ariz., U.S. Bureau of Reclamation, Yuma Area Office. Yuma, Arizona

Cowardin, L.M., Carter, Virginia, Golet, F.C., and La Roe, E.T., 1977, Classification of Wetlands and Deep Water Habitants of the United States (an Operational Draft): U.S. Fish and Wildlife Services, 100 p.

Davis, Stanley N., and DeWiest, Roger J.M.,1967, Hydrogeology: New York, John 
Wiley \& Sons, Inc., 2d Edition.

Glenn, E.P., Felger, R., Burquez, A., and Turner, D., 1992, Cienega de Santa Clara:

Endangered Wetlands in the Colorado Delta: Na tural Resources Journal, vol. 32, p. 817 824.

Glenn, E.P., Riley, J., and Baumgartner, D., 1994, Salinity Effects on Growth,

Distribution and Evapotranspiration of Typha Domingensis (Cattail) in Cienega de Santa

Clara: Tucson, Ariz., Environmental Resourc e Laboratory, University of Arizona.

Huguenin, Robert L., 1994, Process Improves Accuracy of Multispectral Classification: Earth Observation Magazine.

Instituto Nacional de Estadística, Geografía e Informatíca, 1981, Carta Topografica de E1 Doctor H11B1 7, 1:50,000 Scale.

Instituto Nacional de Estadística, Geografía e Informatíca, 1982, Carta Topografica de Oviedo Mota I11D87, 1:50,000 Scale.

Jensen, A.,1980, Seasonal Changes in Near Infrared Reflectance Ratio and Standing Crop Biomass in a Salt Marsh Community Dominated by Halimione Portulacoides (L.) Allen: New Phytol. vol.80, p. 57-67.

Morrow, J.W., and Carter, V., 1978, Wetland Classification on the Alaskan North Slope: 5th Canadian Symposium on Remote Sensing, Victoria, British Columbia, Canada .

Pfeiffer, W.J., Linthurst, R.A., and Gallagher, J.L., 1973, Photographic Imagery and Spectral Properties of Salt Marsh Vegetation as Indicator of Canopy Characteristics: Proceedings of the American Society of Photogrammetry, p.1001 -1015.

Sanchez, R.D. and Hothem, L., 1998, Field mapping using high -resolution digital images and global positioning system and geographic information system data: Proceedings of the Meeting of the American Society of Photogrammetry and Remote Sensing, Tampa Bay, Fla., March 1998, CD-ROM.

Sturdevant, J.A.,1981, "Assessing Accuracy of Digital Land Use and Terrain Data": Proceedings of the Meeting of American Society of Photogrammetry and Remote Sensing, San Francisco, Calif., p. $101-112$.

U.S. Department of Defense, 1984, Fed eral Radionavigation Plan: Technical Report, No. DOD-4650.4, p. 1-204. 


\section{APPENDIX A}

SPECTRAL PROPERTIES DATA

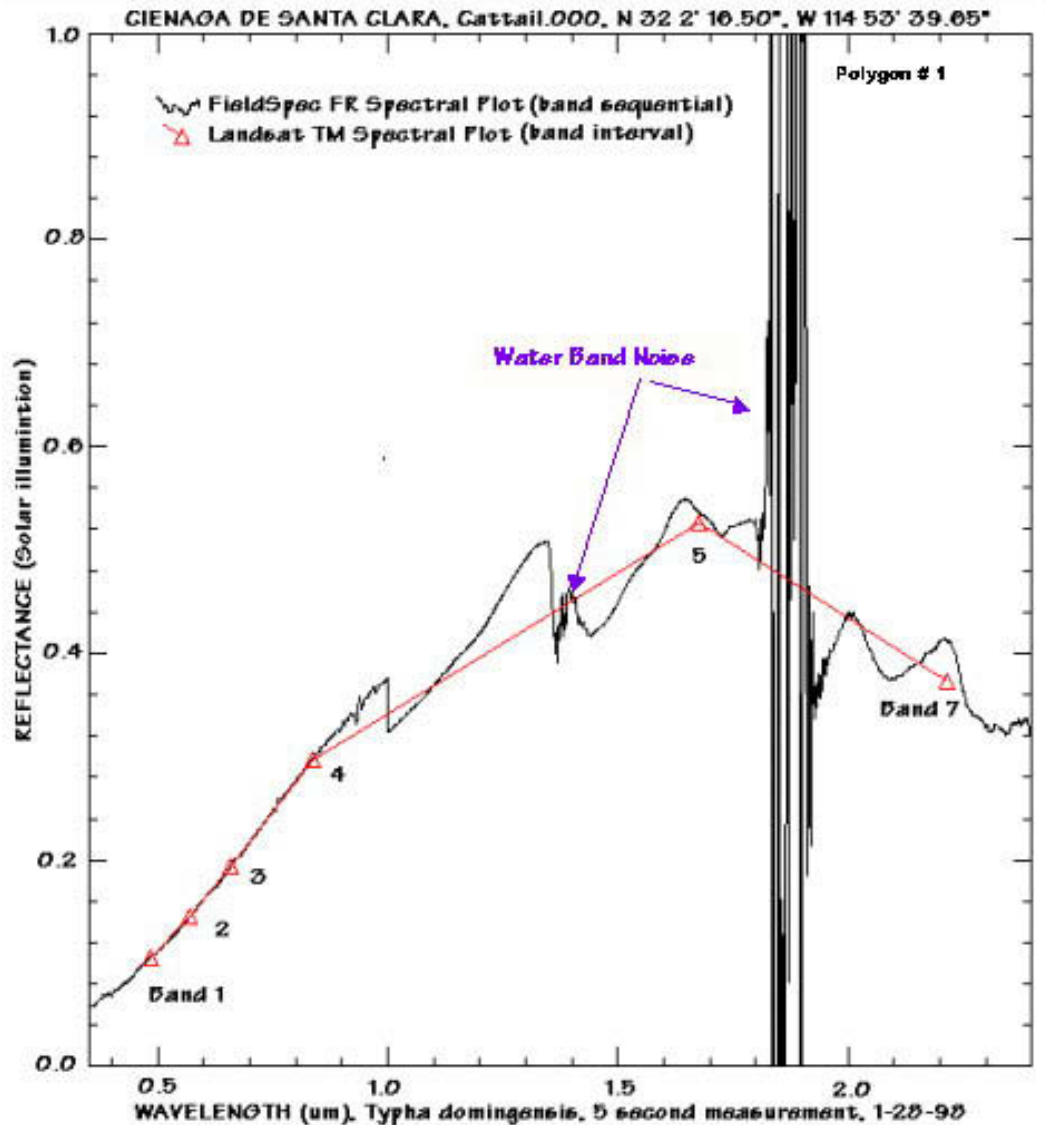

Spectral profile for the vegetation cattail or Typha domingensis (in black) from spectra collected January 28 , 1998, and the same reference spectrum resampled to match the spectral resolution of Landsat 5 thematic mapper (TM) sensor (red). The lower signal to noise ratio in the regions of 1.450 um and $1.875 \mathrm{um}$ are associated with the water vapor absorption bands. Multispectral TM sensor acquires imagery from 0.45 to 12.4 um in seven nonsequential band intervals. Band 6 , the thermal band (10.4 to $12.4 \mathrm{um}$ ), is not shown 


\section{APPENDIX A}

SPECTRAL PROPERTIES DATA

A-2
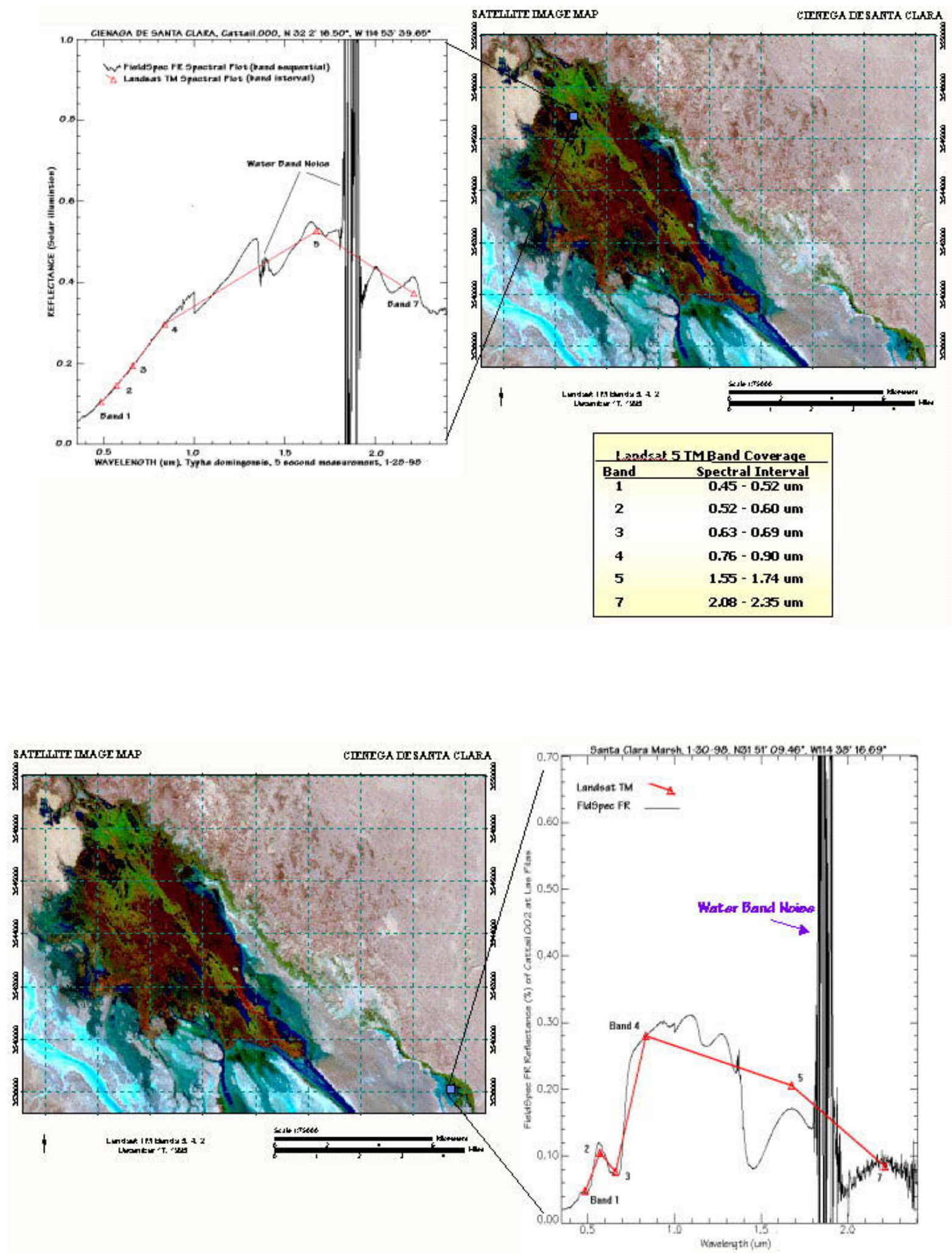


\section{APPENDIX A}
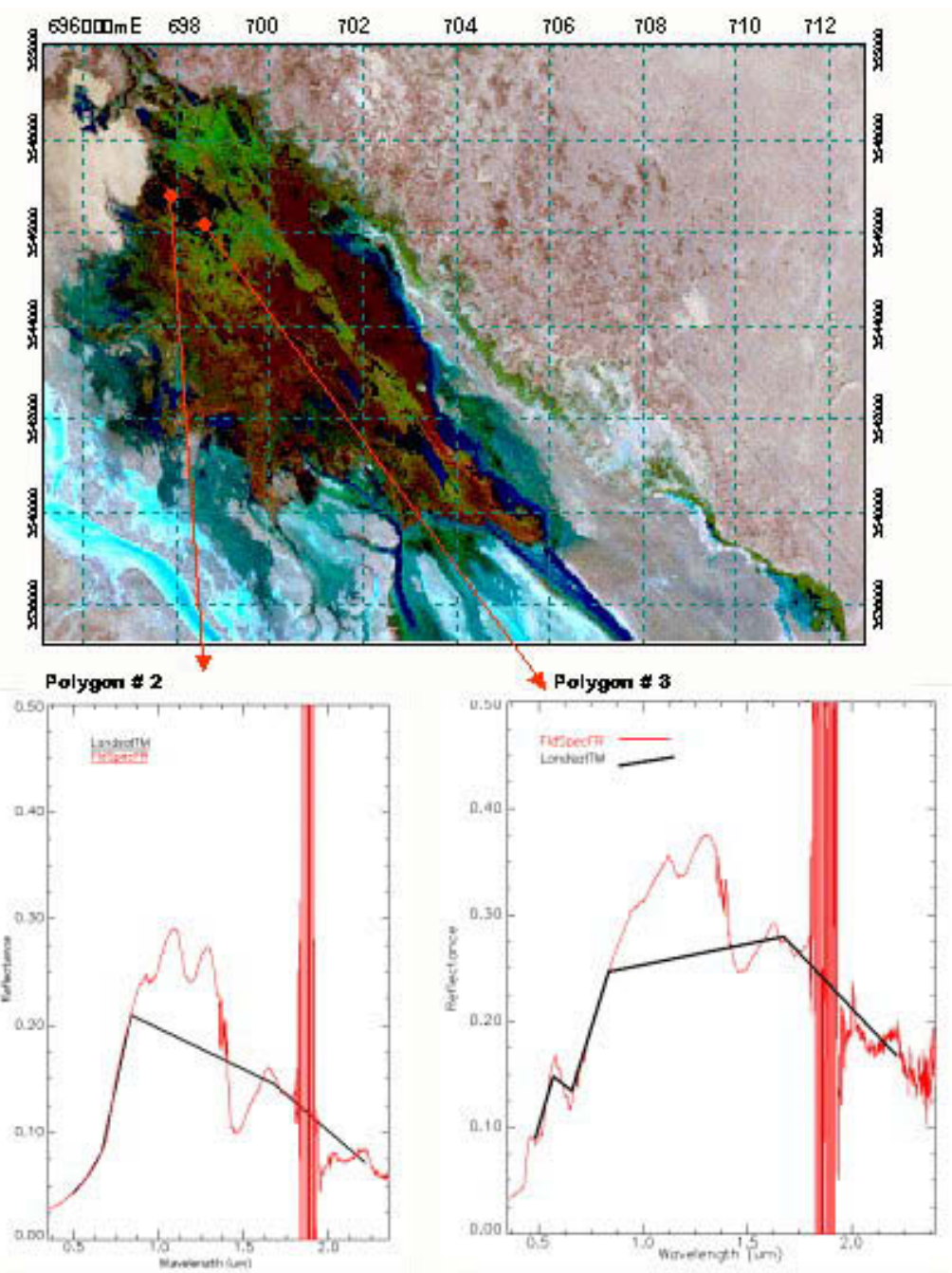

Spectral profile for the vegetation cattail or Typha domingensis (in red) from spectra collected January 28 , 1998, and the same reference spectrum resampled to match the spectral resolution of Landsat 5 thematic mapper (TM) sensor (in black). The lower signal to noise ratio in the regions of 1.450 um and $1.875 \mathrm{um}$ are associated with the water vapor absorption bands.

Multispectral TM sensor acquires imagery from 0.45 to 12.4 um in seven nonsequential band intervals. Band 6 , the thermal band ( 10.4 to $12.4 \mathrm{um}$ ), is not shown 


\section{APPENDIX B}

WATER AND SEDIMENT DATA ${ }^{1}$

\begin{tabular}{|c|c|c|c|c|c|}
\hline $\begin{array}{l}\text { WATER } \\
\text { SAMPLE \# }\end{array}$ & $\begin{array}{c}\text { LOCATION } \\
\text { (Lat/Long/Ht) } \\
\end{array}$ & $\begin{array}{l}\text { DATE of } \\
\text { Collection } \\
\end{array}$ & TDS (Evap.) & $\begin{array}{l}\text { EC (micro- } \\
\text { siemens/cm) }\end{array}$ & $\mathrm{pH}$ \\
\hline 1 & $\begin{array}{l}031^{\circ} 14^{\prime} \quad 29.03 " \mathrm{~N} \\
115^{\circ} 05^{\prime} 04.28^{\prime \prime} \mathrm{W} \\
\mathrm{MSL} 3.2 \mathrm{~m}\end{array}$ & $1 / 19 / 00$ & 2,880 & 4,330 & 7.9 \\
\hline 2 & $\begin{array}{l}032^{\circ} 03^{\prime} 07.75^{\prime \prime} \mathrm{N} \\
114^{\circ} 54^{\prime} 04.48^{\prime \prime} \mathrm{W} \\
\text { MSL } 1 \mathrm{~m}\end{array}$ & $1 / 20 / 00$ & 3,920 & 6,000 & $\mathrm{~N} / \mathrm{A}$ \\
\hline 3 & $\begin{array}{l}032^{\circ} 03^{\prime} 06.88^{\prime \prime} \mathrm{N} \\
114^{\circ} 52^{\prime} 57.24^{\prime \prime} \mathrm{W} \\
\text { MSL } 7 \mathrm{~m}\end{array}$ & $1 / 20 / 00$ & 5,800 & 9,500 & N/A \\
\hline 4 & $\begin{array}{l}032^{\circ} 03^{\prime} 13.58^{\prime \prime} \mathrm{N} \\
114^{\circ} 53^{\prime} 00.81^{\prime \prime} \\
\text { MSL } 9 \mathrm{~m}\end{array}$ & $1 / 20 / 00$ & 14,500 & 19,000 & $\mathrm{~N} / \mathrm{A}$ \\
\hline 5 & $\begin{array}{l}032^{\circ} 02^{\prime} 02.76 " \mathrm{~N} \\
114^{\circ} 51^{\prime} 27.17^{\prime \prime} \mathrm{W} \\
\text { MSL } 9 \mathrm{~m}\end{array}$ & $1 / 20 / 00$ & 6,160 & 10,000 & $\mathrm{~N} / \mathrm{A}$ \\
\hline 6 & $\begin{array}{l}032^{\circ} 01^{\prime} 45.78^{\prime \prime} \mathrm{N} \\
114^{\circ} 51^{\prime} 52.19^{\prime \prime} \mathrm{W} \\
\text { MSL } 1 \mathrm{~m}\end{array}$ & $1 / 21 / 00$ & 6,590 & 10,000 & 8.2 \\
\hline 7 & $\begin{array}{l}032^{\circ} 01^{\prime} 45.72^{\prime \prime} \mathrm{N} \\
114^{\circ} 51^{\prime} 52.26^{\prime \prime} \mathrm{W} \\
\text { MSL } 2.2 \mathrm{~m}\end{array}$ & $1 / 21 / 00$ & 6,320 & 9,630 & 8.2 \\
\hline 8 & $\begin{array}{l}032^{\circ} 01^{\prime} 54.75^{\prime \prime} \mathrm{N} \\
114^{\circ} 51^{\prime} 37.69 " \mathrm{~W} \\
\text { MSL } 7.2 \mathrm{~m}\end{array}$ & $1 / 21 / 00$ & 16,700 & 24,400 & 8.4 \\
\hline 9 & $\begin{array}{l}031^{\circ} 51^{\prime} 09.46 " \mathrm{~N} \\
114^{\circ} 38^{\prime} 16.69 " \mathrm{~W} \\
\text { MSL } 5 \mathrm{~m}\end{array}$ & $1 / 30 / 98$ & 1,520 & 2,730 & 7.4 \\
\hline 10 & $\begin{array}{l}031^{\circ} 51^{\prime} 07.97^{\prime \prime} \mathrm{N} \\
114^{\circ} 38^{\prime} 18.21^{\prime \prime W} \\
\text { MSL } 1 \mathrm{~m}\end{array}$ & $1 / 30 / 98$ & 10,100 & 16,200 & 8.24 \\
\hline
\end{tabular}

${ }^{1}$ Source: Water analysis of samples 1-8 by Yuma Desalting Plant Laboratory, samples $9-10$ by Environmental Research Chemistry Laboratory, Bureau of Reclamation, Denver Technical Service Center. Sample 9 above taken from Las Pilas artesian well. 


\section{APPENDIX B}

WATER AND SEDIMENT DATA ${ }^{2}$

\begin{tabular}{|c|c|c|c|c|}
\hline $\begin{array}{c}\text { SOIL } \\
\text { SAMPLE \# }\end{array}$ & $\begin{array}{c}\text { LOCATION } \\
\text { (Lat/Long/Ht.) } \\
\end{array}$ & $\begin{array}{l}\text { DATE of } \\
\text { Collection }\end{array}$ & $\%$ SALT & $\mathrm{pH}$ \\
\hline 1 & $\begin{array}{l}032^{\circ} 02^{\prime} 16.50^{\prime \prime} \mathrm{N} \\
114^{\circ} 53^{\prime} 39.65^{\prime \prime} \mathrm{W} \\
\text { MSL } 9 \mathrm{~m}\end{array}$ & $1 / 30 / 98$ & 0.75 & 8.0 \\
\hline $2 A$ & $\begin{array}{l}032^{\circ} 02^{\prime} 13.99^{\prime \prime} \mathrm{N} \\
114^{\circ} 53^{\prime} 57.20^{\prime \prime} \mathrm{W} \\
\mathrm{MSL} 7 \mathrm{~m}\end{array}$ & $1 / 30 / 98$ & 1.12 & 8.2 \\
\hline $2 B$ & $\begin{array}{l}032^{\circ} 02^{\prime} 13.99^{\prime \prime} \mathrm{N} \\
114^{\circ} 53^{\prime} 57.20^{\prime \prime} \mathrm{W} \\
\mathrm{MSL} 7 \mathrm{~m}\end{array}$ & $1 / 30 / 98$ & 0.52 & 8.3 \\
\hline $3 A$ & $\begin{array}{l}032^{\circ} 02^{\prime} 01.35^{\prime \prime} \mathrm{N} \\
114^{\circ} 53^{\prime} 40.57^{\prime \prime} \mathrm{W} \\
\text { MSL } 8 \mathrm{~m}\end{array}$ & $1 / 30 / 98$ & 1.21 & 8.4 \\
\hline 3B & $\begin{array}{l}032^{\circ} 02^{\prime} 01.35^{\prime \prime} \mathrm{N} \\
114^{\circ} 53^{\prime} 40.57^{\prime \prime W} \\
\text { MSL } 8 \mathrm{~m}\end{array}$ & $1 / 30 / 98$ & 1.47 & 8.2 \\
\hline 4 & $\begin{array}{l}031^{\circ} 51^{\prime} 07.97^{\prime \prime} \mathrm{N} \\
114^{\circ} 38^{\prime} 18.21^{\prime \prime W} \\
\text { MSL } 1 \mathrm{~m}\end{array}$ & $1 / 30 / 98$ & 0.35 & 8.7 \\
\hline
\end{tabular}

${ }^{2}$ Source: Soil analysis by Environmental Research Chemistry Laboratory, Bureau of Reclamation, Denver Technical Services Center 